Mini Review

\title{
Challenges for the successful aging of LGBT older adults
}

\begin{abstract}
The aging of older lesbians, gays, bisexuals and transgender people (LGBT) may have some particularities and challenges. They can suffer from the ageism of society, and from the consequences of loneliness, for example. ${ }^{1}$

Besides that, some researches of the aging field have already suggested that "heterosexual aging" study models and data would be insufficient to understand the complexities and particularities of old-age experiences of people who express non-hegemonic forms of sexuality. ${ }^{1}$

Few studies have addressed this issue, especially in the Brazilian medical literature. In addition, the geriatrician and gerontologist may encounter challenging situations in their practices when assisting an older LGBT person with dementia or even at their end of life. ${ }^{2}$

The aim of this article was not only to uncover the loneliness and invisibility of LGBT older people. But also, to reveal the experiences of the Brazilian Non-Governmental Organization "Eternamente SOU" and how such activities can help to promote active and successful aging.
\end{abstract}

Volume 4 Issue 4 - 2019

\author{
Milton Roberto Furst Crenitte \\ Geriatrics Service, University of São Paulo School of Medicine \\ Hospital das Clínicas, Brazil
}

Correspondence: Milton Roberto Furst Crenitte, Geriatrics Service, University of São Paulo School of Medicine Hospital das Clínicas - São Paulo (SP), Brazil,

Email milton.crenitte@gmail.com

Received: July 27, 2019 | Published: August 19, 2019

\section{Introduction}

Since the 1940s, researchers have been searching for the best definition for the concept of successful aging. ${ }^{3}$ In 2008, Young and colleagues ${ }^{4}$ expounded the state in which the person can recruit psychosocial and social adaptive resources to compensate physiological limitations and ensure a sense of well-being and quality of life, even in a disease context and inability.

In this sense, Fredriksen-Goldsen and colleagues ${ }^{5}$ studied the aging of lesbian, gay, bisexual and transgender (LGBT), and developed a resiliency model to explain the conditions attached to its successful aging.

In this model, internalized homophobia, ${ }^{6}$ which is the negative feeling LGBT may have about itself, lack of access to health services, obesity and functional limitation represent the risk factors. Then, social support and the size of its network represent the protective factors. ${ }^{5}$ Thus, discussion also began on the importance of subjective activities and experience as necessary and independent components in these aspects.

Therefore, the objectives of this article were: problematizing the loneliness and invisibility of LGBT older people, the account of the experiences of the Non-Governmental Organization Eternamente SOU and how such activities can help to promote active and successful aging.

\section{Social isolation and loneliness of LGBT older people}

Older LGBT people are at greater risk of having no children, living alone, being unmarried, having no family to call in an emergency, having experienced any prior violence and having used or abused alcohol and drugs. ${ }^{7-9}$

Other issues related to aging are also determining factors for the individual to feel alone, such as retirement, the death of a loved one and changes in housing, income and health. ${ }^{7-9}$ In addition to the direct potential impact on health, with the increased risk of cardiovascular disease and poor control of depression and anxiety, the loneliness and social isolation these people suffer may also have negative repercussions on the follow-up of patients with dementia, ${ }^{10}$ and even in Palliative Care. ${ }^{11}$

\section{Seeing the invisibility of LGBT older people}

Who knows the story of Grace and Frankie, Jane Fonda and Lily Tomlin characters in the Netflix series, also know the drama of their husbands, Robert and Sol, which decides to divorce their wives to marry each other.

In a classic example of "life imitating art," understanding why it took them so long to "get out of the closet" can help to understand the current generation of LGBT seniors.

If Robert and Sol were 80 years old today, in 1973 they were 44, when the American Psychiatric Association ceased to consider homosexuality as a disease. In addition, at age 50 they began to hear about AIDS and at age 60 some of their close friends began to die from the disease.

For these two, and for many of their LGBT contemporaries, invisibility was a found way to escape discrimination, and in some cases to survive. However, remaining invisible at this age can have detrimental consequences on all health-related bio-psycho-social dimensions. ${ }^{2}$ For one side, this invisibility, as already mentioned, can increase your sense of loneliness.

On the other hand, people who "come out of the closet" and talk to their doctors about their sexual orientation and gender identity expose higher levels of satisfaction. They even have better access to health services, better control of their chronic diseases and greater adherence to health promotion guidelines. ${ }^{12}$ Data from Canada show that lesbian older women express higher risks than heterosexual women from not having mammograms or pap smears, and a high chance of not having 
a trusted doctor. ${ }^{13,14}$ Even depression and suicide are more common in this group, expressing more impactful rates among trans aged people. $^{15}$

In addition, research involving this portion of the population shows that they suffer a "double invisibility". They experience stigma because they are older in a society that values mainly youth-related aspects and also because they are LGBT, as the community judges their sexuality as deviant. ${ }^{2}$

\section{In Brazil: perspectives and challenges}

Considerable progress has been made towards public policies aimed at LGBT segmentation in Brazil in recent years, but much remains to be done. ${ }^{2}$

The LGBTfobia is a reality that needs to be considered and confronted by laws that quantify, qualify and monitor the violence for reasons of hatred and intolerance in order to ensure proper treatment for these situations, as well as the visibility of the cause and the society's awareness of its confrontation.

Thus, in 2017 the collective Eternamente SOU, who subsequently was formed as a non-governmental organization (NGO), in order to give visibility to issues that guide this segment, with a focus on performance directly with LGBT seniors, in the participation of the militancy to implement specific public policies for this population and also in the qualification and training of professionals working in the social and health care network, thus favouring a gerontological culture more sensitive to the specificities of this population, uniting knowledge and experiences.

This NGO also conducts events and socio-educational activities to promote self-awareness, autonomy, independence and empowerment of LGBT older people through artistic languages such as Body Expression, Theater, monthly themed meetings, among others.

These activities favour the strengthening of affective bonds and of belonging, relevant to the strengthening of social support network and to face the loneliness and the isolation. ${ }^{16-18}$

\section{Final considerations}

LGBT aging is marked by double invisibility and particular health needs. Future research and discussions, especially in Brazil, are needed to create more inclusive health environments and to combat the loneliness and social isolation of these people, making their geriatric and gerontological care even better.

\section{Acknowledgement}

I would like to thank Dr Wilson Jacob Filho, chief of geriatrics service at the Clinics Hospital of the Medicine School of University of Sao Paulo, for his support.

\section{Conflict of interest}

The author declare no conflict of interest.

\section{Funding details}

The author declares that the article was written with personal resources.

\section{References}

1. Henning, CE. Gerontologia LGBT: velhice, gênero, sexualidade e constituição dos idosos LGBT. Horiz antropol. 2017;23(47): 283-323.

2. Crenitte MRF, Miguel DF, Filho WJ. An approach to the peculiarities of lesbian, gay, bisexual and transgender aging. Geriatr Gerontol Aging. 2019;13(1):50-56.

3. Strawbridge WJ, Wallhagen MI, Cohen RD. Successful aging and wellbeing self-rated compared with Rowe and Kahn. The Gerontologist. 2002;42:727-733.

4. Young Y, Frick KD, Phelan EA. Can successful aging and chronic illness coexist in the same individual? A multidimensional concept of successful aging. Journal of the American Medical Directors Association. 2009;10:87-92.

5. Fredriksen GK, Shiu C, Goldsen J, et al. Successful Aging among LGBT older adults: physical and mental health related quality of life by age group. Gerontologist. 2015;55(1):154-68.

6. Pereira H, Leal I. A homofobia internalizada e os comportamentos para a saúde numa amostra de homens homossexuais. Revista Análise Psicológica. Instituto Universitário Ciências Psicológicas, Sociais e da Vida. Lisboa: ISPA; 2002.

7. Bauer, M, McAulie, I and Nay R. Sexuality, health care and the older person: an overview of the literature. International Journal of Older People Nursing. 2007;2(1):63-68.

8. Shankle MPH, Maxell C, Katzman E, et al. An invisible population: older lesbian, gay, bisexual and transgender individuals. Clinical Research and Regulatory Affairs. 2003;20:159-82.

9. Cahill S, South K, Spade J. Outing age: public policy issues affecting gay, lesbian, bisexual, and transgender elders. Washington, DC: The Policy Institute of the National Gay and Lesbian Task Force Foundation; 2000.

10. Peel E, Taylor H, Harding R. Sociolegal and practice implications of caring for LGBT people with dementia. Nurs Older People. 2016;28(10):26-30.

11. Hughes, M, Cartwright, C. LGBT people's knowledge of and preparedness to discuss end-of-life care planning options. Health Soc Care Community. 2014;22:545-52.

12. Baker K, Beagan B. Making assumptions, making space: an anthropological critique of cultural competency and its relevance to queer patients. Medical Anthropology Quarterly. 2014;28:579-598.

13. Brotman S, Ryan B, Cormier R. The health and social service needs of gay and lesbian elders and their families in Canada. Gerontologist. 2003;43(2):192-202.

14. Brotman S, Ryan B, Collins S, et al. Coming out to care: Caregivers of gay and lesbian seniors in Canada. Gerontologist. 2007; 47(4):490-503.

15. Yarns BC, Abrams JM, Meeks TW, et al. The Mental Health of Older LGBT Adults. Curr Psychiatry Rep. 2016;18:60.

16. http://www.eternamentesou.org/

17. Neri AL, Teixeira INDA. Envelhecimento bem-sucedido: uma meta no curso da vida. Psicol Usp. 2008;19(1):81-94.

18. Pruchno, RA, Wilson-Genderson M, Rose M, et al. Successful aging: Early influences and contemporary characteristics. The Gerontologist. 2010;50:821-833 